\title{
PENGGUNAAN EKSTRAK DAUN LAMTORO (Leucaena Leucocephala) SEBAGAI PUPUK DENGAN SALINITAS YANG BERBEDA TERHADAP LAJU PERTUMBUHAN, BIOMASSA DAN KLOROFIL-A PADA MIKROALGA CHLORELLA VULGARIS
}

\author{
Ana Evita Auliaa, ${ }^{a}$, Yunita Maimunah ${ }^{a}$, Heny Suprastyani ${ }^{a}$ \\ ${ }^{a}$ Program Studi Budidaya Perairan, Fakultas Perikanan Dan Ilmu Kelautan, Universitas Brawijaya, \\ Jalan Veteran Malang 65145, Indonesia
}

*Korespondensi penulis : anaevita@student.ub.ac.id

\begin{abstract}
Abstrak
Kultur Chlorellah vulgaris umumnya menggunakan pupuk Pro Analisis (PA), mahalnya harga pupuk PA menjadi dasar pencarian pupuk alternatif yang mampu memenuhi kebutuhan nutrisi C. vulgaris. Pupuk alternatif yang digunakan yaitu pupuk organik berbahan baku daun lamtoro (L. leucocephala) yang diekstrak. Tujuan dari penelitian ini yaitu menganalisis pengaruh perbedaan salinitas dan menganalisis nilai salinitas yang optimal pada pupuk ekstrak daun lamtoro untuk laju pertumbuhan, biomassa dan klorofil-a C. vulgaris. Metode yang digunakan dalam penelitian ini yaitu dengan metode eksperimen Rancangan Acak Lengkap (RAL) dengan empat perlakuan dan empat ulangan. Perlakuan yang diberikan pada penelitian ini adalah pupuk ekstrak daun lamtoro (L. leucocephala) dosis 1,75 ml/l dengan salinitas $30 \mathrm{ppt}, 35 \mathrm{ppt}, 40 \mathrm{ppt}$ dan kontrol (walne 1 $\mathrm{ml} / \mathrm{l}$ ) salinitas $30 \mathrm{ppt}$. Parameter utama yang diamati yaitu pertumbuhan, biomassa dan klorofil-a C. vulgaris. Hasil penelitian menunjukkan bahwa pemberian pupuk ekstrak daun lamtoro (L. leucocephala) dengan salinitas yang berbeda berpengaruh nyata terhadap pertumbuhan, biomassa dan klorofil-a C. vulgaris. Perlakuan terbaik selama penelitian didapatkan hasil laju pertumbuhan spesifik 1,94/hari pada salinitas 35 ppt, biomassa sebesar 0,403 g/l pada salinitas $35 \mathrm{ppt}$ dan klorofil-a sebesar 0,018 $\mu \mathrm{g} / \mathrm{ml}$ pada salinitas $35 \mathrm{ppt}$. Berdasarkan hasil penelitian ini, disarankan agar menggunakan salinitas 34 untuk penelitian selanjutnya, karena sesuai dengan hasil maksimum dari perhitungan statistika agar mendapatkan hasil yang lebih baik.
\end{abstract}

Kata Kunci: Biomassa, Chlorella vulgaris, Ekstrak daun lamtoro, Klorofil-a

\begin{abstract}
Chlorella vulgaris cultivation generally used Pro Analysis (PA) fertilizer, the high price of PA fertilizer is the based for finding alternative fertilizer that can supply the nutrient requirement of $C$. vulgaris. The alternative fertilizer used is organic fertilizer made from extracted leaves of lamtoro (L. leucocephala). The purpose of this study was to analyze the effect of differences in salinity and to analyze the optimal salinity value of lamtoro leaf extract fertilizer for growth rate, biomass and chlorophyll-a C. vulgaris. The method used in this study was the experimental method completely randomized design (CRD) with four treatments and four replications. The treatment given in this study was lamtoro leaf extract (L. leucocephala) dosage of $1.75 \mathrm{ml} / \mathrm{l}$ with $30 \mathrm{ppt}, 35$ ppt, $40 \mathrm{ppt}$ salinity and $30 \mathrm{ml} \mathrm{ppt}$ (walne $1 \mathrm{ml} / \mathrm{l}$ ) salinity control. The main parameters observed were growth, biomass and chlorophyll-a C. vulgaris. The results showed that the administration of lamtoro (L. leucocephala) leaf extract fertilizer with different salinity significantly affected the growth, biomass and chlorophyll-a $C$. vulgaris. The best treatment during the study resulted in a specific growth rate of 1.94/ day at a salinity of 35 ppt, biomass of $0.403 \mathrm{~g} / \mathrm{l}$ at a salinity of $35 \mathrm{ppt}$ and chlorophyll-a of $0.018 \mu \mathrm{g} / \mathrm{ml}$ at a salinity of $35 \mathrm{ppt}$. Based on the results of this study it is recommended to use 34 salinity for further research, because it is in accordance with the maximum statistical calculation results in order to get better results.
\end{abstract}

Keywords: Biomass, Chlorella vulgaris, Lamtoro leaf extract, Chlorophyll-a 


\section{PENDAHULUAN}

Mikroalga merupakan organisme autotrof yang tumbuh melalui proses fotosintesis. Mikroalga dapat tumbuh dengan sangat cepat pada kondisi iklim yang tepat dalam jangka waktu 24 jam atau bahkan 3,5 jam selama fase pertumbuhan eksponensial [1]. Mikroalga pada bidang budidaya digunakan sebagai pakan alami bagi larva ikan, bisa juga sebagai pakan sekunder seperti Rotifera, Copepoda, Artemia dan Brachionus [2]. Fitoplankton memiliki klorofil yang mampu melakukan fotosintesis sehingga menjadi sumber protein, karbohidrat, lemak, vitamin dan mineral bagi organisme air [3].

Chlorella vulgaris salah satu mikroalga yang telah dimanfaatkan sebagai pakan alami, pakan ternak dan suplemen. $C$. vulgaris mengandung berbagai nutrien seperti protein, karbohidrat, asam lemak tak jenuh, vitamin, klorofil, enzim, serat yang tinggi. Sel $C$. vulgaris memiliki tingkat reproduksi yang tinggi, setiap sel $C$. vulgaris mampu berkembang menjadi 10.000 sel dalam waktu 24 jam [4]. C. vulgaris juga membutuhkan unsur makro $\mathrm{N}$ dan $\mathrm{P}$ untuk meningkatkan laju pertumbuhan. Pertumbuhan C. vulgaris sangat dipengaruhi oleh beberapa faktor lingkungan, diantaranya unsur hara dalam media kultur serta kualitas air seperti salinitas, $\mathrm{pH}$, suhu, intensitas cahaya yang optimum [5].

Faktor nutrien adalah salah satu faktor penting yang perlu diperhatikan dalam pertumbuhan mikroalga. Nutrien yang dibutuhkan oleh mikroalga terdiri dari makronutrien dan mikronutrien. Makronutrien yang dibutuhkan antara lain $\mathrm{C}, \mathrm{H}, \mathrm{N}, \mathrm{P}, \mathrm{K}, \mathrm{S}$, $\mathrm{Mg}$, dan $\mathrm{Ca}$, sedangkan mikronutrien yang dibutuhkan antara lain adalah $\mathrm{Fe}, \mathrm{Cu}, \mathrm{Mn}, \mathrm{Zn}$, Co, Mo, Bo, Vn, dan Si [6]. Penambahan nutrisi pertumbuhan ke dalam media kultur mikroalga dinilai merupakan aspek yang paling berpengaruh terhadap kuantitas biomassa hasil kultivasi mikroalga [7].

Persediaan $C$. vulgaris sebagai pakan alami didapatkan dari media kultur akan menghasilkan hasil terbaik, terutama mengenai jumlah sel atau kepadatan $C$. vulgaris yang dihasilkan. Karena setiap media mempunyai komposisi unsur hara yang berbeda antara satu media dengan yang lain, masing-masing unsur hara tersebut juga mempunyai fungsi yang berbeda pula bagi phytoplankton yang akan dibudidayakan [8]. Daun lamtoro memiliki kandungan nutrisi berupa 3,84\% N; 0,20\% P; $0,206 \% \mathrm{~K} ; 1,31 \% \mathrm{Ca}$ dan $0,33 \% \mathrm{Mg}$ yang mampu meningkatkan pertumbuhan dan perkembangannya yaitu dengan memanfaatkan daun lamtoro sebagai media kultur alternatif yang memiliki unsur makronutrien dan mikronutrien yang dibutuhkan oleh $C$. vulgaris [9].

Kebutuhan N, P dan K rasio yang optimal bagi pertumbuhan $C$. vulgaris yakni sebesar 2:1:6 [10]. Ekstrak daun lamtoro memiliki kandungan makronutrien seperti fosfor, nitrogen, magnesium kalium dan kalsium. Dalam 100g daun lamtoro basah terdapat N, P dan $\mathrm{K}$ rasio 7:1:9 [11]. Hasil uji analisis N, P dan $\mathrm{K}$ yang telah dilakukan, kandungan $\mathrm{N}, \mathrm{P}$ dan K pada daun lamtoro yaitu 2,52\% N; 0,21\% $\mathrm{P}$ dan $1,63 \% \mathrm{~K}$. Berdasarkan hasil uji analisis kimia daun lamtoro, didapatkan rasio 12:1:8. Daun lamtoro juga dapat dimanfaatkan sebagai pupuk kompos pada tanaman seperti sawi dan bayam merah. Pemberian kompos lamtoro pada berbagai konsentrasi berpengaruh positif terhadap pertumbuhan bayam merah [12]. Pupuk organik (daun lamtoro) memberikan pengaruh yang signifikan terhadap pertumbuhan tanaman sawi [13]. Ketersediaan daun lamtoro yang melimpah dan mudah didapatkan serta dapat dengan mudah tumbuh hampir di semua tempat yang mendapatkan curah hujan cukup. Dengan demikian, dapat dimanfaatkan secara kontinu [14].

Faktor lingkungan merupakan faktor yang mempengaruhi pertumbuhan salah satunya adalah salinitas. Salinitas media kultur $C$. vulgaris agar tumbuh optimal pada kisaran salinitas 25-34 ppt [15]. Salinitas dan pH merupakan parameter yang penting dalam pertumbuhan mikroalga. Faktor salinitas sangat penting karena, berpengaruh terhadap tekanan osmotik tubuh. Produktivitas dan daya adaptasi berbagai jenis mikroalga diduga berkaitan erat dengan tingkat salinitas lingkungannya. Kisaran optimum salinitas pada media pemeliharaan 25-35 ppt [16]. Salinitas adalah faktor eksternal yang dapat menjadi pemicu utama stres dan salinitas ekstrem akan menjadi penghambat pertumbuhan pada biota air. Salinitas yang ekstrem juga akan menyebabkan tekanan osmotik dan atau pertukaran ion yang berpengaruh terhadap metabolisme organisme fotosintetis. Sejumlah penelitian telah 
menemukan efek salinitas terhadap pertumbuhan mikroalga [17].

Salinitas merupakan parameter yang penting, kadar salinitas pada media kultur sangat mempengaruhi kepadatan mikroalga. Besar kecilnya kadar salinitas berpengaruh terhadap tekanan osmotik dan mekanisme osmoregulasi yang secara langsung akan mempengaruhi proses metabolisme, proses respirasi serta menghambat proses pembiakan sel vegetatif selanjutnya secara bertahap akan mempengaruhi kepadatan populasi mikroalga. Salinitas di perairan menimbulkan tekanantekanan osmotik yang bisa berbeda dari tekanan osmotik di dalam tubuh organisme perairan, sehingga menyebabkan organisme tersebut harus melakukan mekanisme osmoregulasi di dalam tubuhnya sebagai upaya menyeimbangkan tekanan osmotik tubuh dengan tekanan osmotik lingkungan di luar tubuh [18]. Konsentrasi Salinitas yang terlalu tinggi akan mempengaruhi pertumbuhan dari mikroalga secara signifikan, dengan adanya tekanan osmotik berpengaruh terhadap ukuran sel mikroalga [19].

Tujuan dari penelitian ini yaitu untuk mengetahui pengaruh perbedaan salinitas pada media pupuk ekstrak daun lamtoro terhadap laju pertumbuhan, biomassa dan klorofil-a $C$. vulgaris dan untuk mengetahui nilai salinitas yang optimal pada pupuk ekstrak daun lamtoro untuk laju pertumbuhan, biomassa dan klorofila $C$. vulgaris.

\section{METODOLOGI}

\section{Waktu dan Tempat}

Penelitian ini dilaksanakan di Laboratorium Budidaya Ikan Divisi Reproduksi Ikan, Laboratorium Budidaya Ikan Divisi Penyakit dan Kesehatan ikan, Laboratorium Unit Perikanan Air Tawar Sumberpasir, Fakultas Perikanan dan Ilmu Kelautan Universitas Brawijaya, Malang pada bulan 6 Januari 2020 - 30 Maret 2020.

\section{Materi Penelitian}

Peralatan yang digunakan dalam penelitian ini yaitu autoklaf, blower, lampu TL 40 watt (4 buah), erlenmeyer $(50 \mathrm{ml}, 100 \mathrm{ml}$, $250 \mathrm{ml}$ dan $500 \mathrm{ml}$ ), hot plate, spektrofotometer, buret statif, toples plastik $3 \mathrm{~L}$, vortex, mikroskop binokuler, beaker glass (50 $\mathrm{ml}$ dan $250 \mathrm{ml})$, gelas ukur $(25 \mathrm{ml}, 250 \mathrm{ml}$ dan $1000 \mathrm{ml}$ ), timbangan digital, lux meter, nampan, selang aerasi, spatula kaca, $\mathrm{pH}$ meter, DO meter, termometer, haemocytometer 0,1 $\mathrm{mm}$, bola hisap D\&N, pipet tetes, corong, mikropipet, bluetip, handtally counter, washing bottle, cover glass, cuvet, kalkulator, botol sprayer, botol film, petridish, cawan petri, vacum pump VE115, tabung reaksi dan pipet volume $(1 \mathrm{ml}, 5 \mathrm{ml}$ dan $10 \mathrm{ml})$. Bahan yang digunakan dalam penelitian yaitu bibit inokulan C. vulgaris yang didapat dari Situbondo, Jawa Timur, air laut yang memiliki salinitas $36 \mathrm{ppt}$ berasal dari toko ikan hias tirta mutiara, Malang, alkohol 76\%, kapas, plastik $1 \mathrm{~kg}$, karet, tisu, kertas Wattman GF/C dengan diameter 90 $\mathrm{mm}$, vitamin, pupuk walne, akuades, kertas kora, kertas saring, kain saring, pupuk urea, aluminium foil, plastic wrap, $\mathrm{SnCl}_{2}$, amonium molybdate, $\mathrm{NH}_{4} \mathrm{OH}$, pupuk walne, vitamin $\mathrm{B} 12$, methanol absolute, asam fenol disulfonik, kertas label dan metanol.

\section{Rancangan Penelitian}

Rancangan Acak Lengkap (RAL) dengan empat perlakuan. Perlakuan yang digunakan diantaranya yaitu perlakuan dengan pemberian pupuk ekstrak daun lamtoro (L. leucocephala) dosis $1,75 \mathrm{ml} / 1$ dengan konsentrasi salinitas yang berbeda A (30 ppt), B (35 ppt), C (45 ppt) dan kontrol walne $1 \mathrm{ml} / \mathrm{l}(30 \mathrm{ppt})$. Masingmasing perlakuan dilakukan dengan pengulangan sebanyak empat kali.

\section{Prosedur Kerja}

Tahap awal kultur dalam penelitian ini adalah proses sterilisasi. Sterilisasi yang digunakan dalam penelitian ini meliputi sterilisasi panas basah, sterilisasi kimia, dan perebusan. Kedua, menyiapkan media kultur yaitu air tawar dan air laut. Ketiga, menyiapkan bibit $C$. vulgaris yang diperoleh dari kultur murni BPBAP Situbondo. Keempat, pembuatan pupuk ekstrak daun lamtoro (L. leucocephala), daun lamtoro (L. leucocephala) didapatkan dari alam. daun lamtoro (L. leucocephala) dipisahkan dari tangkainya, ditimbang sebanyak 100gram dan dicuci dengan menggunakan air sampai bersih kemudian di blender dengan pencampuran $500 \mathrm{ml}$ akuades, selanjutnya penyaringan daun lamtoro yang 
telah diblender. Hasil ekstrak yang telah disaring kemudian disterilisasi menggunakan autoklaf dan diendapkan selama 24 jam hingga terbentuk dua lapisan yaitu supernatan dan endapan [20]. Selanjutnya mempersiapkan dosis pupuk yang digunakan pupuk ekstrak daun lamtoro 1,75 ml/1, $\mathrm{NaH}_{2} \mathrm{PO}_{4}$ 0,005 gram/1 dan pupuk Walne $1 \mathrm{ml} / \mathrm{l}$ Kelima, mempersiapkan air laut dan air tawar yang sudah disesuaikan dengan perlakuan salinitas.

Pelaksanaan penelitian dimulai dengan penyiapan media kultur di dalam rak penelitian sebanyak enam belas botol plastik dengan masing-masing berisi media $2.000 \mathrm{ml}$ dengan penambahan dosis pupuk ekstrak daun lamtoro (L. leucocephala) $1,75 \mathrm{ml} / 1$, vitamin dengan dosis $1 \mathrm{ml} / \mathrm{l}$ dan $\mathrm{NaH}_{2} \mathrm{PO}_{4}$ 0,005 gr/l dengan perlakuan konsentrasi salinitas yang diberikan yaitu 30 ppt, 35 ppt dan 40 ppt. Kontrol berupa pemberian pupuk walne dan vitamin dengan dosis $1 \mathrm{ml} / \mathrm{l}$, kemudian diberikan aerasi. Langkah selanjutnya inokulan $C$. vulgaris ditebar dengan kepadatan awal $1 \times 10^{5} \mathrm{sel} / \mathrm{ml}$. Toples kaca ditutup menggunakan plastik dan diikat dengan karet. Pengamatan dan perhitungan pertumbuhan $C$. vulgaris dilakukan setiap hari selama masa kultur. Pengukuran parameter utama lainnya seperti laju pertumbuhan dilakukan pengukuran sekali sehari, biomassa, dan klorofil-a $C$. vulgaris dilakukan pada saat fase eksponensial. Parameter pendukung yang diukur meliputi suhu, $\mathrm{pH}$, salinitas, nitrat dan fosfat. Adapun pengukuran suhu, $\mathrm{pH}$, dan salinitas dilakukan sekali sehari, sedangkan pengukuran nitrat dan fosfat dilakukan pada awal penanaman (hari ke0) dan fase eksponensial (hari ke-5).

\section{Analisis Pertumbuhan}

Laju pertumbuhan spesifik $(\mu)$ dianalisis menggunakan persamaan berikut [21]:

$$
\mu=\frac{\ln N \max -\ln N o}{\operatorname{Tmax}-T o}
$$

dimana $\mu$ merupakan laju pertumbuhan spesifik (hari ${ }^{-1}$ ), Nmax dan N0 merupakan kepadatan sel tertinggi dan kepadatan sel awal (sel/ml), Tmax dan N0 merupakan waktu yang dibutuhkan untuk mendapatkan kepadatan maksimal dan waktu awal tebar (hari).

\section{Analisis Biomassa}

Konsentrasi biomassa sel $S$. Platensis dianalisis menggunakan metode [22]. Sampel mikroalga yang digunakan diambil pada saat fase stasioner. Kertas saring GF/C (mesh size $1,2 \mu \mathrm{m}$ ) dikeringkan pada suhu $105^{\circ} \mathrm{C}$ selama 2 jam hingga beratnya konstan [A]. Sampel mikroalga $25 \mathrm{ml}$ difilter melalui kertas saring GF/C dan dicuci dengan $25 \mathrm{ml}$ air tawar untuk menghindari kontaminasi garam yang tidak larut pada media. Kemudian kertas saring diletakkan di oven pada suhu $105^{\circ} \mathrm{C}$ selama 2 jam hingga beratnya konstan. Setelah dingin, kertas saring diletakkan di desikator, kemudian beratnya ditimbang kembali [B].

Biomassa $(\mathrm{mg} / \mathrm{l})=(\mathrm{B}-\mathrm{A}) \times 1000 /$ Volume Sampel

\section{Analisis Klorofil-a}

Pehitungan klorofil-a yaitu dengan menggunakan cara modifikasi [23], langkah pertama yang dilakukan yaitu diambil $5 \mathrm{~mL}$ sampel mikroalga lalu dimasukkan dalam falcon dan dibungkus aluminium foil tertutup rapat. Sentrifugasi pada $5.000 \mathrm{rpm}$ selama 20 menit dan dibuang supernatannya. Lakukan proses freezing-thawing masing-masing 15 menit (hingga membeku dan mencair) sebanyak 3 kali ulangan. Ditambahkan $5 \mathrm{~mL}$ methanol absolute lalu divortex selama 15 detik. Tahap selanjutnya campuran (endapan dan pelarut) diletakkan pada hot plate dengan suhu $70^{\circ} \mathrm{C}$ selama 30 menit. Sampel diinkubasi pada suhu $4^{0} \mathrm{C}$ selama keadaan gelap 24 jam. Kemudian sampel divortex dan dilakukan sentrifugasi $5.000 \mathrm{rpm}$ selama 20 menit. Dilakukan pengukuran menggunakan spektrofotometer dengan panjang gelombang $665 \mathrm{~nm}$ dan $652 \mathrm{~nm}$. Perhitungan klorofil-a menurut [24], yaitu:

$\mathrm{Chl}$ a $(\mu \mathrm{g} / \mathrm{mL})=-2,6839 \times \mathrm{OD}_{652}+13,2654 \times$ $\mathrm{OD}_{665}$

\section{Analisis Data}

Penelitian ini menggunakan Rancangan Acak Lengkap (RAL) dalam model penelitiannya. Data pengamatan parameter utama pada seluruh perlakuan diuji menggunakan uji ANOVA (Analysis of Variance $)$ ) pada tingkat kepercayaan $95 \%(\alpha=$ $0,05)$. Apabila dari data sidik ragam diketahui bahwa perlakuan berpengaruh nyata (F hitung > 
F tabel 5\%) maka dilanjutkan dengan uji Beda Nyata Terkecil (BNT). Uji BNT untuk menguji perbedaan pada seluruh perlakuan menggunakan selang kepercayaan $95 \%(\alpha=$ 0,05 ) sehingga diperoleh hasil perlakuan terbaik dalam penelitian. Selanjutnya dilakukan uji Polynomial Orthogonal untuk memperoleh dosis terbaik dan kurva respon terhadap parameter serta menentukan persamaan hubungan perlakuan yang diberikan terhadap parameter penelitian.

\section{HASIL DAN PEMBAHASAN}

Pertumbuhan $C$. vulgaris pada media pupuk ekstrak daun lamtoro (L. leucocephla) dengan konsentrasi salinitas yang berbeda (30 ppt, 35 ppt dan 40 ppt) diperoleh laju pertumbuhan spesifik, biomassa dan klorofil-a C. vulgaris pada Tabel 1 .

Tabel 1. Laju pertumbuhan spesifik, biomassa dan klorofil-a C. vulgaris

\begin{tabular}{|c|c|c|c|c|}
\hline \multirow[b]{2}{*}{ Parameter } & \multicolumn{3}{|c|}{ Perlakuan Salinitas } & \multirow[b]{2}{*}{$\begin{array}{l}\text { Kontrol } \\
\text { (30 ppt) }\end{array}$} \\
\hline & $\begin{array}{c}\text { A } \\
30 \text { ppt }\end{array}$ & $\begin{array}{c}\text { B } \\
35 \text { ppt }\end{array}$ & $\begin{array}{c}C \\
40 \mathrm{ppt}\end{array}$ & \\
\hline $\begin{array}{l}\text { Laju Pertumbuhan } \\
\text { Spesifik (/hari) }\end{array}$ & $\begin{array}{l}1,81 \pm \\
0,095^{\mathrm{a}}\end{array}$ & $1,94 \pm 0,084^{\mathrm{c}}$ & $1,913 \pm 0,047^{\mathrm{b}}$ & $2,06 \pm 0,04^{\mathrm{d}}$ \\
\hline Biomassa $(\mathrm{g} / \mathrm{l})$ & $\begin{array}{l}0,31 \pm \\
0,046^{b}\end{array}$ & $0,40 \pm 0,11^{\mathrm{c}}$ & $0,18 \pm 0,004^{\mathrm{a}}$ & $0,17 \pm 0,02^{\mathrm{a}}$ \\
\hline Klorofil - a (mg/l) & $\begin{array}{l}0,01 \pm \\
0,004^{\mathrm{c}}\end{array}$ & $0,018 \pm 0,003^{\mathrm{a}}$ & $0,011 \pm 0,001^{\mathrm{a}}$ & $0,017 \pm 0,005^{\mathrm{b}}$ \\
\hline
\end{tabular}

Keterangan : notasi berbeda menunjukkan adanya pengaruh di setiap perlakuan; kepercayaan $95 \%(\alpha=0,05)$

Pengaruh Salinitas Terhadap pertumbuhan C. vulgaris

Berdasarkan perhitungan analisis statistik hubungan antara pemberian pupuk ekstrak daun lamtoro ( $L$. leucocephala) dengan konsentrasi salinitas yang berbeda berpengaruh nyata terhadap laju pertumbuhan spesifik $C$. vulgaris didapatkan kurva respons dengan pola kuadratik. Hasil laju pertumbuhan spesifik $C$. vulgaris pada masing-masing perlakuan dapat dilihat pada Tabel 1.

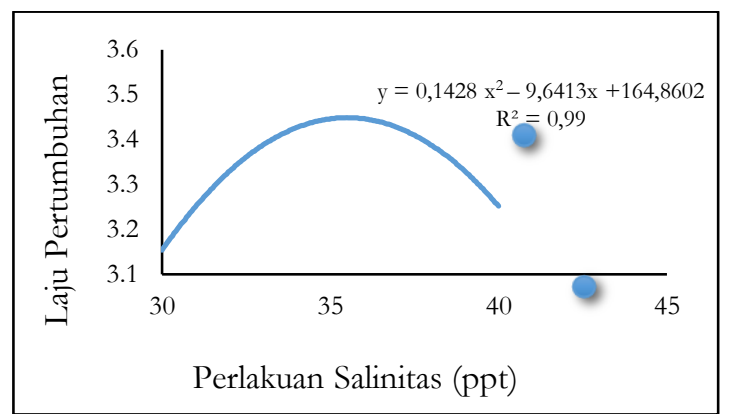

Gambar 1. Hubungan Konsentrasi Salinitas Terhadap Laju Pertumbuhan Spesifik C. vulgaris

Laju pertumbuhan spesifik $C$. vulgaris disajikan pada Gambar 1. Berdasarkan dari perhitungan statistika tersebut didapatkan regresi sebesar 0,99 hal tersebut membuktikan bahwa nilai salinitas pada media kultur sangat mempengaruhi laju pertumbuhan dari $C$. vulgaris sebesar $0,99 \%$ dan didapatkan hasil terbaik pada salinitas 35 ppt yaitu sebesar 1 , 94/hari dengan doubling time selama 0,357 hari. Perlakuan kontrol memiliki laju pertumbuhan spesifik lebih tinggi yaitu sebesar 2,06/hari dengan doubling time selama 0,33 hari. [25], menyatakan bahwa semakin tinggi laju pertumbuhan spesifik maka menunjukkan daya dukung media terhadap mikroalga semakin baik. Laju pertumbuhan spesifik menurun pada salinitas $30 \mathrm{ppt}$ dan 40 ppt. Salinitas sangat berpengaruh penting pada media yang mempengaruhi laju pertumbuhan mikroalga, untuk mempertahankan tekanan osmotik antara sel dengan air sebagai lingkungan hidup mikroalga. Hasil laju pertumbuhan tersebut menunjukkan adanya pengaruh salinitas pada media kultur. Salinitas rendah akan menyebabkan sel mikroalga mengalami keadaan hipotonik, yaitu kondisi larutan pada lingkungan memiliki konsentrasi yang lebih rendah dibandingkan cairan dalam sel mikroalga (sel akan mengembang). Sedangkan, salinitas tinggi akan menyebabkan sel mikroalga mengalami keadaan hipertonik, dimana kondisi larutan pada lingkungan memiliki konsentrasi yang lebih tinggi dibanding kondisi cairan dalam sel mikroalga (sel mengalami penyusutan dan mengerut) [26].

Pertumbuhan Chlorella menurun sejalan dengan meningkatnya salinitas begitu juga 
menurunnya salinitas. Dikarenakan salinitas sangat berpengaruh terhadap tekanan osmosis dalam sel dan mekanisme osmoregulasi yang secara langsung dapat mempengaruhi sistem metabolisme yang berakibat terhadap penurunan populasi sel mikroalga [27].

Salinitas merupakan faktor yang penting dalam pembentukan pigmen, produksi biomassa dan pertumbuhan sel. Salinitas sebagai faktor pembatas pertumbuhan dari mikroalga. Salinitas optimum pada media kultur $C$. vulgaris yaitu berkisar 30-35 ppt [28].

\section{Pengaruh Salinitas Terhadap Biomassa $C$. vulgaris}

Berdasarkan perhitungan analisis statistik hubungan antara pemberian pupuk ekstrak daun lamtoro (L. Lucocephala) dengan konsentrasi salinitas yang berbeda berpengaruh nyata terhadap biomassa $C$. vulgaris didapatkan kurva respons dengan pola kuadratik.

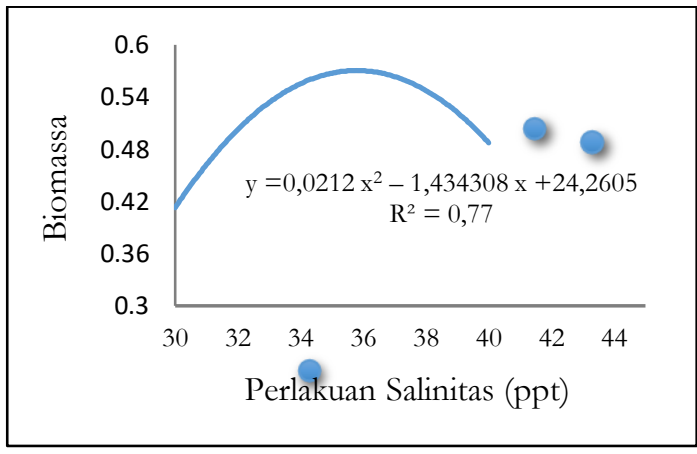

Gambar 2. Hubungan Konsentrasi Salinitas terhadap Biomassa $C$. vulgaris

Biomassa C. vulgaris yang disajikan pada Gambar 2. Berdasarkan dari perhitungan statistika tersebut didapatkan regresi sebesar 0,77 hal tersebut membuktikan bahwa nilai salinitas pada media kultur berpengatuh pada nilai biomassa dari $C$. vulgaris sebesar $0,77 \%$ dan didapatkan hasil terbaik pada salinitas 35 ppt mampu menghasilkan produksi biomassa sebesar 0,403 g/l. Produksi biomassa menurun pada konsentrasi salinitas 30 ppt dan 40 ppt. Pada salinitas 35 ppt merupakan salinitas terbaik untuk pertumbuhan dan pembentuk biomassa $C$. vulgaris. Hasil biomassa tersebut menunjukkan adanya pengaruh dari salinitas yang terkandung dalam pupuk ekstrak daun lamtoro (L. Leucocephala). Salah satu parameter yang berpengaruh terhadap akumulasi jumlah biomassa fitoplankton dalam kultur salah satunya yaitu salinitas. Salinitas memiliki peran pada kelangsungan hidup mikroalga dan dapat menyebabkan penghambatan aktivitas metabolisme akibat menurunnya fotosintesis yang berkaitan dengan pembentukan biomassa.

Pembentukan biomassa $C$. vulgaris akan turun pada media dengan salinitas rendah atau terlalu tinggi, hal tersebut berhubungan dengan menurunnya efisiensi fotosintesis akibat stress disebabkan oleh salinitas. [29] menyatakan bahwa, saat mikroalga tumbuh pada media yang memiliki salinitas terlalu tinggi atau terlalu rendah, mikroalga akan mengeluarkan tenaga lebih untuk mempertahankan tekanan osmotik dan menyebabkan penurunan biomassa atau terjadinya penrunan pertumbuhan mikroalga.

\section{Pengaruh Salinitas Terhadap Klorofil-a $C$. vulgaris}

Berdasarkan perhitungan analisis statistik hubungan antara pemberian pupuk ekstrak daun lamtoro (L. leucocephala) dengan salinitas yang berbeda berpengaruh nyata terhadap kandungan klorofil-a $C$. vulgaris didapatkan kurva respons dengan pola kuadratik.

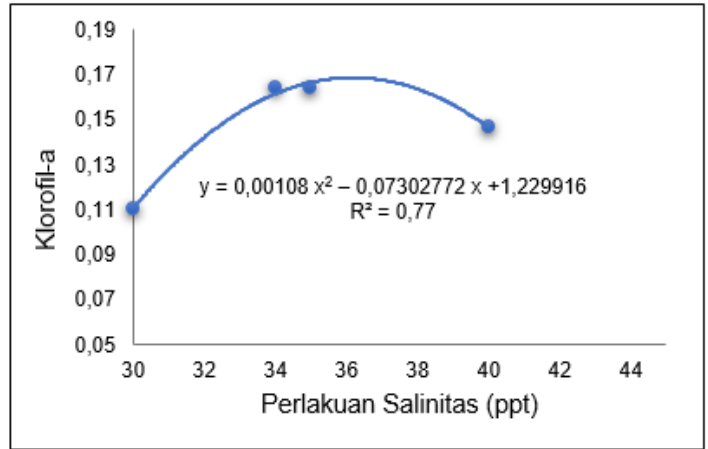

Gambar 3. Hubungan Konsentrasi Salinitas terhadap Klorofil-a C. vulgaris

Kandungan klorofil-a $C$. vulgaris yang disajikan pada Gambar 3. Berdasarkan dari perhitungan statistika tersebut didapatkan regresi sebesar 0,77 hal tersebut membuktikan bahwa nilai salinitas pada media kultur berpengaruh pada nilai klorofil-a dari $C$. vulgaris sebesar $0,77 \%$ dan didapatkan hasil terbaik pada salinitas 35 ppt mampu menghasilkan kandungan klorofil-a sebesar 0,056 $\mu \mathrm{g} / \mathrm{ml}$. Perlakuan kontrol memiliki kandungan klorofila yaitu sebesar $0,052 \mu \mathrm{g} / \mathrm{ml}$. Kandungan klorofil-a menurun pada salinitas 30 ppt dan 40 ppt. Hasil kandungan klorofil-a tersebut 
menunjukkan adanya pengaruh dari konsentrasi salinitas yang berbeda. salinitas merupakan faktor yang penting dalam pembentukan pigmen, produksi biomassa dan pertumbuhan sel dari mikroalga [30].

Salinitas berpengaruh terhadap tekanan osmotik yang mempengaruhi pembentukan pigmen. Stressing salinitas baik dibawah maupun diatas salinitas normal, akan mengakibatkan menurunnya sintesa pigmen pada mikroalga.

\section{KESIMPULAN}

Hasil penelitian menunjukkan bahwa pemberian pupuk ekstrak daun lamtoro $(L$. leucocephala) dengan konsentrasi salinitas yang berbeda pada media pupuk ekstrak daun lamtoro berpengaruh nyata terhadap laju pertumbuhan, biomassa dan klorofil-a $C$. vulgaris dan konsentrasi salinitas terbaik pada media pupuk ekstrak daun lamtoro untuk proses pertumbuhan $C$. vulgaris 35 ppt dengan hasil laju pertumbuhan spesifik 1,93/hari, berat biomassa sebesar $0,40 \mathrm{~g} / \mathrm{L}$ dan klorofil-a $0,018 \mu \mathrm{g} / \mathrm{ml}$.

\section{DAFTAR PUSTAKA}

[1] Abyor., N. $\mathrm{H}$ dan D. Ariyanti. 2012.Potensi Mikroalga Sebagai Sumber Biomasa dan Pengembangan Produk Turunannya. Teknik. 33(2): 58-65.

[2] Erlina., A, S. Amini, H. Endrawati dan M. Zainuri. 2004.Kajian Nutritif Phytoplankton Pakan Alami pada Sistem Kultivasi Massal. Ilmu Kelautan. 9(4): 206-210.

[3] Sukmawati., M. A, N. S. Antara dan I. W. Arnata. 2014. Optimization salinity and initial $\mathrm{pH}$ on the biomass production of Nannochloropsis sp. K-4. Jurnal Rekayasa dan Manajemen Agroindustri. 2(1): 19-28.

[4] Betawati., N. P, B. Putri dan R. Yuniati. 2005. Pertumbuhan Chlorella vulgaris Spp. Dalam Medium Ekstrak Tauge (Met) dengan Variasi pH Awal. Makara Sains. 9(1): 1-6.

[5] Meritasari., D, A. S. Mubarok, L. Sulmartiwi dan E. D. Masithah. 2012.
Pengaruh Pemberian Pupuk Cair Limbah Ikan Lemuru (Sardinella Sp.) Dengan Dosis Yang Berbeda Terhadap Pertumbuhan Chlorella vulgaris Jurnal Ilmiah Perikanan dan Kelautan. 4(1): 2732.

[6] Bagus., I. G. B, A. A. M. D. Anggreni dan I. B. W. Gunam. 2015. Pengaruh Konsentrasi Penambahan Sodium Nitrat Dan Sodium Fosfat Pada Media Guillard Terhadap Konsentrasi Biomassa Mikroalga Nannochloropsis sp.. Jurnal Rekayasa Dan Manajemen Agroindustri. 3(4):73-81.

[7] Kadek., N. E. Juniantari, A.A.M. D. Anggreni dan I. B. W. Gunam. 2015. Pengaruh Jenis Media Terhadap Pertumbuhan Nannochloropsis Sp.. Jurnal Rekayasa Dan Manajemen Agroindustri. 3(2): 1-9.

[8] Chilmawati., D dan Suminto. 2008. Penggunaan Media Kultur Yang Berbeda Terhadap Pertumbuhan Chlorella vulgaris Jurnal Saintek Perikanan. 4(1): 42 - 49.

[9] Mahardani. D, B, Putri dan S. Hudaidah. 2017. Pengaruh Salinitas Berbeda Terhadap Pertumbuhan dan Kandungan Karotenoid Dunaliella sp. Dalam Media Ekstrak Daun Lamtoro (Leucaena leucocephala). Jurnal Perikanan dan Kelautan. 7(1): $50-58$.

[10] Aini., Q. W, Winarsih dan A. Bashri. 2019. Pengaruh Pemberian Pupuk Organik Cair Berbahan Baku Limbah Sisa Makanan dengan Penambahan Berbagai Bahan Organik terhadap Pertumbuhan Tanaman Sawi (Brassica juncea L.). LenteraBio. 8(2): 136-142.

[11] Ningsih., R. Z, H. Fitrihidajati dan Y. S. Rahayu. 2013. Pengaruh penambahan daun lamtoro terhadap kualitas kompos kertas-Lamtoro dan pemanfaatannya terhadap pertumbuhan tanaman bayam merah. LenteraBio. 2(1):149-154.

[12] Pary., C. 2015. Pengaruh pupuk organk (daun lamtoro) dalam berbagai konsentrasi terhadap pertumbuhan 
tanaman sawi. Jurnal Fikratuna. 7(2): 246-255.

[13] Pardede., N. S. 2017. Pemberian tepung daun lamtoro (Leucaena leucocephala) dalam ransum terhadap performans burung puyuh (Coturnix-coturnix Javonica). Jurnal Peternakan. 1(1):22-26.

[14] Regista., Ambeng, M. Litaay dan M. R. Umar. 2017. Pengaruh Pemberian Vermikompos Cair Lumbricus Rubellus Hoffmeister Pada Pertumbuhan Chlorella vulgaris The Research On The Effect Giving Liquid Vermikompost Lumbricus Rubellus On The Growth Of Chlorella vulgaris. Jurnal Biologi Makassar. 2(1):18.

[15] Arif., M. S, N. S. Antara dan I. W. Arnata. 2014. Optimization Salinity And Initial Ph On The Biomass Production Of Nannochloropsis sp. K-4. Jurnal Rekayasa dan Manajemen Agroindustri. 2(1):19-28.

[16] Djunaedi., A, Sunaryo, C. A. Suryono dan A. Santosa. 2017. Kandungan Pigmen Fikobiliprotein dan Biomassa Mikroalga Chlorella vulgaris pada media dengan Salinitas Berbeda. Jurnal Kelautan Tropis. 20(2):112-116.

[17] Pamungkas., W. 2012. Aktivitas osmoregulasi, respons pertumbuhan dan energetic cost pada ikan yang dipelihara dalam lingkungan bersalinitas. Media Akuakultur. 7(1): 44-51.

[18] Duan., X, G. Y. Ren, L. L. Liu dan W. X. Zhu. 2012. Salt-induced osmotic stress for lipid overproduction in batch culture of Chlorella vulgaris vulgaris. Journal of Biotechnology. 11(27): 7072-7078.

[19] Septiana, I. 2016. Pertumbuhan dan kandungan karotenoid Mikroalga Dunaliella sp. dalam media ekstrak daun lamtoro (Leucaena leucocephala). Skripsi. Fakultas Pertanian Universitas Lampung Bandar Lampung.

[20] Kawaroe., M, T. Prartono, A. Sunuddin, D. W. Sari dan D. Augustine. 2009. Laju pertumbuhan spesifik Chlorella sp. Dan Dunaliella $s p$. Berdasarkan perbedaan nutrien dan fotoperiode. Jurnal Ilmu-ilmu Perairan dan Perikanan Indonesia. 16(1): 73-77.

[21] Janssen, M., T. C. Kuijpers, B. Veldhoen, M. B. Ternbach, J. Tramper, R. H. Wijffels. 1999. Specific growth rate of Chlamydomonas reinhardtii and Chlorella vulgaris sorokiniana under medium duration light:dark cycles: 13-87 s. Journal of Biotechnology. 70: 323-333.

[22] Bennett, A. And L. Bogoard. 1973. Complementary chromatic adaptation in a filamentous blue-green alga. Journal of cell biology. 58 (2): 419-435.

[23] Ritchie R. 2006. Consistent sets of spectrophotometric chlorophyll equations for acetone, methanol and ethanol solvents. Photosynthesis Research. 89: $27-41$.

[24] Zainuddin., M, N. Hamid, L. Mudiarti, N. Kursistyanto dan B. Aryono. 2017. Pengaruh media hiposalin dan hipersalin terhadap respon pertumbuhan dan biopigmen Dunaliella salina. Jurnal enggano. 2(1): 46-57.

[25] Rafaelina. M., Y. Rustam dan S. Amini. 2016. Pertumbuhan dan aktivitas antioksidan dari mikroalga Porphyridium cruentum dan Chlorella sp.. BIOMA. 12(1): 12-21.

[26] Lukitasari., M. 2015. Biologi Sel. Universitas Negeri Malang

[27] Sutomo., 1991. Pengaruh salinitas dan $\mathrm{pH}$ terhadap pertumbuhan Chlorella sp.. Biologi. 1(1): 39-47.

[28] Kasim., S, P. Taba, I. Raya dan Ruslan. 2017. Potensi produksi biofuel dari bomassa fitoplankton laut spesies Chlorella vulgaris, Dunaliella salina dan Spirulina sp., yang ditumbuhkan dalam nutrien unggul "MSSIP" terinduksi ion logam Fe, Co dan Ni. KOVALEN. 3(1): 89-111. 
[29] Na Gu., Qiang Lin. Gang Li. Yehui Tan. Liangmin Huang dan Junda Lin. 2012. Effect of salinity on growth, biochemical composition and lipid productivity of Nannochloropsis oculata CS 179. 12(6): 631-637.

[30] Adenan, N.S., F. Md. Yusoff, M. Shariff. 2013. Effect of Salinity and Temperature on the Growth of Diatoms and Green Algae. Journal of Fisheries and Aquatic Science. 8(2): 397-404. 